\title{
ХАРАКТЕРИСТИКА СИНДРОМА НАРУШЕННОГО РАСПОЗНАВАНИЯ ГИПОГЛИКЕМИИ У ДЕТЕЙ ПОДРОСТКОВОГО ВОЗРАСТА С САХАРНЫМ ДИАБЕТОМ 1 ТИПА
}

\author{
Иванова А.А., Демяненко А.Н., Алимова И.Л. \\ ФГБОУ ВО «Смоленский государственный медицинский университет» МЗ РФ, Смоленск
}

ЦЕЛЬ: изучить результаты многофункционального исследования гликемии, ЭКГ и ЭЭГ у детей подросткового возраста с синдромом нарушенного распознавания гипогликемии.

МАТЕРИАЛЫ И МЕТОДЫ: обследовано 23 подростка с сахарным диабетом 1 типа в возрасте 12-17 лет, находящихся на базисно-болюсной инсулинотерапии и проводящих самоконтроль с помощью глюкометра. Проводилось анкетирование по методу Clarke (4 балла и более свидетельствовали о нарушенном распознавании гипогликемии (НРГ)), а также параллельное мониторирование гликемии (i-Pro2) и ЭЭГ (Энцефалан-ЭЭГР-19/26) с 23.00 до 7.00. По результатам анкетирования пациенты были распределены на 2 группы: 1-я группа-с НРГ (n=9), 2-я группа-без НРГ (n=14). Статистическая обработка проводилась с помощью программы Statistica 7.0 (StatSoft 2009).

РЕзУЛЬтАТЫ: пациенты обеих групп были сопоставимы (р>0,05) по полу, возрасту, длительности диабета, уровню гликированного гемоглобина. По данным мониторинга гликемии в 1-й группе было выделено 8 эпизодов гипогликемии ( $\leq 3,9$ ммоль/л), во 2-й-4 эпизода. В 1-й группе 6 (75\%) эпизодов гипогликемии регистрировались в диапазоне клинически значимых (<3,0 ммоль/л) пролонгированных (более 120 минут) бессимптомных гипогликемий, во 2-й группе бессимптомных пролонгированных гипогликемий не отмечалось.

По данным ЭЭГ при гипогликемии в 1-й и 2-й группах с одинаковой частотой $(p>0,05)$ регистрировались пароксизмальные нарушения (6(75\%) и 3(75\%) соответственно), гиперсинхронный ритм (5(83\%) и 1(25\%)), заостренные волны (2(33\%) и 0(0\%)), экстраполярная ЭКГ (6(100\%) и 2 (50\%)), что свидетельствовало о наличии процессов, направленных на активацию ЦНС при низком содержании глюкозы. Сочетанные нарушения ЭЭГ регистрировались у большинства пациентов с НРГ (6 (75\%)), у пациентов без НРГ сочетанных нарушений на ЭЭГ не отмечалось $(p=0,017)$. Это отражает дезорганизацию функциональной активности ЦНС у пациентов 1-й группы. У пациентов с НРГ была установлена прямая корреляционная взаимосвязь частоты регистрации бессимптомной гипогликемии с частотой регистрации сочетанных нарушений ЭЭГ: пароксизмальных нарушений и гиперсинхронным ритмом $(r=+0,95, p<0,05)$, а также пароксизмальных нарушений и заостренных волн $(r=+0,95, p<0,05)$.

ВЫвОД: частота синдрома нарушенного распознавания гипогликемии у детей подросткового возраста составляет 39\%. Нарушенное распознавание гипогликемии характеризуется частой бессимптомной пролонгированной гипогликемией и сопровождается дезорганизацией функциональной активности в виде сочетанных нарушений ЭЭГ.

КЛЮЧЕВЫЕ СЛОВА: сахарный диабет; бессимптомная гипогликемия; дети; ЭЭГ. 